\title{
Effect of Baygon Insecticide on the Activities of Total, Alkaline and Acid Phosphatases of Selected Tissues of Albino Rats
}

\author{
*11 Igwenyi, I. O., ${ }^{1}$ Aboh, N., ${ }^{2}$ Nwachukwu, N., ${ }^{1}$ Ibiam, U. A., \\ ${ }^{1}$ Offor, C. E., ${ }^{1}$ Aja, P. M. And ${ }^{1}$ Agbafor, K. N. \\ ${ }^{1}$ Department of Biochemistry, Ebonyi State University, Abakaliki, Ebonyi State, Nigeria \\ ${ }^{2}$ Department of Biochemistry, Federal University of Technology, Owerri, Imo State, Nigeria
}

\begin{abstract}
Effects of "Baygon" (a combination of proporxur, dichlorovos and cyfluthrin) on serum and liver enzymes of albino rats were determined using standard scientific methods, after exposure to the insecticide. Twenty five rats were used for the study and grouped into five according to exposure time that ranged from zero (control) to 1440 minutes. Mean serum and liver alkaline phosphatase activities of the experimental animals increased significantly $(p<0.05)$ upon exposure to the insectside. However, the activity in group E exposed for 1440 minutes showed no significant difference $(p>0.05)$ in both the serum and liver homogenate. This is indicative of possible recovery over time. The mean activities of serum and liver acid phosphatase showed no significant difference $(p>0.05)$ relative to the control. Prostatic acid phosphatase increased upon exposure but decreased with time in the serum. Thus exposure to Baygon insecticide for even a short time alters liver enzymes activities and by extension, liver function. These distortions and fluctuations in activities of the liver enzymes in the serum and liver homogenates after exposure to Baygon insecticide is an indication of hepatotoxic effect of the insecticides while the results observed after prolonged exposure showed that there was possible recovery with time.
\end{abstract}

Key words: Insecticide; enzymes; liver; serum, toxicity.

\section{Introduction}

Every organism is exposed to xenobiotic substances, which may voluntarily or involuntarily be produced from the external or internal environment. Such substances inevitably may provoke some biochemical reactions in order to annul or reduce their toxic effect. Insecticides are agents of chemical or biological origin that control insects (George and David, 2004). It is widely used to combat mosquitoes (vector of malaria parasite), cockroaches (that spread diseases) and other insects that terrorize tropical Africa.

The discovery in Europe in 1939 of the insecticidal value of dichlorodiphenyltrichloroethane (DDT), a synthetic organic compound led to the synthesis of thousands of organic molecules in search of potent chemicals. At the same time, insecticidal organophosphorus compounds were developed in Germany (Carson, 1962). Baygon insecticide is the commonest insecticide used in the fight against malaria in Nigeria.

The effect of insecticides on different tissues of an organism, which will partially have a pronounced toxicity on their physiological activities, is a function of the type of biochemical components (such as enzymes) that are the target of the active ingredient(s) of the insecticide preparation. Owing to this, the effect of Baygon insecticide (an insecticide with combined actions of proporxur; an organophosphate, dichlorovos; a carbamate insecticide and cyfluthrin; a synthetic pyrethroid) in some rat tissues may depend on the concentrations of the target enzymes in the target organs and frequency of exposure, which may either result in acute or chronic toxicity (Bohmont, 1990).

Toxicity is the innate capacity of a chemical to be poisonous. However, all poisoning is dose dependent and toxic response depends on the size of the dose in relation to the size of the victim and extent of exposure. It has been reported that exposure to high doses of insecticides can damage the liver (Tomei et al., 1998).

Baygon insecticide is composed of three major ingredients, each of which can serve as an insecticide if used alone. It is composed of $1 \%$ proporxur, which belongs to a carbamate insecticide; $1 \%$ dichlororvos belonging to organophosphorus insecticides and 0.04\% cyfluthrin (Bohmont, 1990). Consequently, each of the three can exhibit individual and collective (synergistic) effects on biological systems (Hassal, 1990).

In mammals, some internal organs are usually affected and clinical assessment of extent of toxicity would be necessary by measuring the concentration (activity) of certain enzymes, which catalyze sensitive biochemical reactions in such tissues. The target of clinical investigation is an evaluation and comparative analyses of tissues, organs and systems that are involved in metabolism, excretion and other processes. Such systems include nervous, hepatic, urinary, hematological and cardiac systems.

Obstruction of normal functioning and changes in the normal level or activities of certain measurable biochemical parameters form the basis for predicting the course of a clinical investigation. Liver function tests 
help in the detection, diagnosis and evaluation of liver disease; they also help in monitoring therapy and assessments of prognosis. The major enzymes of clinical significance in liver function are the aminotransferases or transaminases (AST and ALT) and the phosphatases: total, acid and alkaline (Burtis and Ashwood, 2003; Raju and Bindu, 2005).

The use of insecticide Baygon is hepatotoxic as the serum alanine transaminase (AL)T levels were significantly higher $(\mathrm{p}<0.05)$ in the experimental groups exposed to the insect. Investigation into the liver homogenate of the exposed revealed a decrease in the liver alanine transaminase (ALT) and after some time, it increased exceedingly. The serum level of aspartate transaminase (AST) of the exposed animals was found to be significantly higher $(\mathrm{p}<0.05)$ than the control group. However, in the liver of the exposed groups, the aspartate trasaminase (AST) level decreased and finally increased after some time. Generally, the serum and liver levels of AST in all the animals increased with prolonged exposure while their respective corresponding activities in the liver changed irregularly. It became evident and apparent that even exposure for a short time to the insecticide may affect some liver functions as reflected by elevated levels of the transaminases (Igwenyi et al., 2008). Consequently, it became imperative to look at the effect on the phosphatases.

OBJECTIVE: Malaria is the commonest disease affecting most people in tropical Africa and the cause of most deaths in the area. Insecticides are used to control the vector (mosquitoes) and people fleet their rooms and most times, sleep under the influence of the insecticide. The objective of this investigation was to evaluate the effect and possible toxicity of the insecticide "Baygon" which enjoy wide acceptance and application on selected organs involved in its metabolism in albino rats.

\section{Design And Methods:}

Male albino rats (Rattus norvegicus) were bought from the animal house of the Department of Vetenary Medicine, University of Nigeria, Nsukka and used for the study. The animals were maintained in standard diet with water available ad libitum. The animals were divided into five (5) groups of five rats each based on the duration of exposure The Baygon insecticide was bought from Abakaliki Main Market in Ebonyi State of Nigeria.

Wister albino rats were chosen and used as the mammalian laboratory animals due to their availability, cost, adaptability and size. There were five groups (groups A, B, C, D and E) with five (5) rats in each group. The animals in groups B, C, D and E were exposed for 10, 30, 60 and 1440 minutes respectively while group A served as the control. The rats were later sacrificed at the expiration of the exposure time while blood and tissue samples were taken after the various duration of exposure. The serum and liver homogenate were analyzed for possible toxicity. This involved the evaluation of certain biochemical parameters in the selected tissues whose levels or activities are affected (increase or decrease) on administration of substance (xenobiotics) such as liver enzymes. These phosphatases include total, alkaline and prostatic acid phosphatase. Spectrophotometric techniques of Wilkinson et al., 1972; Barbara and Daniel, 2005 were used in the enzyme assays.

\section{Results:}

TABLE 1: Average Activity (in iu/L) Alkaline Phosphatase (ALP) Activity in the Liver and Serum.

\begin{tabular}{|c|c|c|}
\hline $\begin{array}{c}\text { Groups based on exposure time in } \\
\text { minutes }\end{array}$ & $\begin{array}{c}\text { Enzyme activity in the Serum in } \\
\text { uu/L. }\end{array}$ & Enzyme activity in the liver in iu/L. \\
\hline $\mathbf{A}-$ Control & $\mathbf{7 9 . 5 3} \pm \mathbf{1 . 2 2}$ & $\mathbf{7 4 . 5 6} \pm \mathbf{0 . 7 4}$ \\
\hline $\mathrm{B}-10$ & $100.02 \pm 0.25$ & $125.20 \pm 0.45$ \\
\hline $\mathrm{C}-30$ & $106.01 \pm 0.17$ & $144.53 \pm 0.32$ \\
\hline $\mathrm{D}-60$ & $109.05 \pm 0.72$ & $108.58 \pm 0.27$ \\
\hline $\mathrm{E}-1440$ & $82.04 \pm 0.70$ & $82.24 \pm 0.21$ \\
\hline
\end{tabular}

TABLE 2: Average Total Acid Phosphatase (ACP) Activity in the Liver and Serum.

\begin{tabular}{|c|c|c|}
\hline $\begin{array}{c}\text { Groups based on exposure time in } \\
\text { minutes }\end{array}$ & $\begin{array}{c}\text { Enzyme activity in the Serum } \\
\text { (iu/L) }\end{array}$ & Enzyme activity in the liver (iu/L) \\
\hline $\mathbf{A}-$ Control & $\mathbf{5 1 . 2 5} \pm \mathbf{3 . 6 4}$ & $\mathbf{9 6 . 2 5} \pm \mathbf{0 . 1 1}$ \\
\hline $\mathrm{B}-10$ & $48.20 \pm 5.16$ & $96.18 \pm 0.21$ \\
\hline $\mathrm{C}-30$ & $48.12 \pm 5.54$ & $97.45 \pm 0.46$ \\
\hline $\mathrm{D}-60$ & $46.10 \pm 0.96$ & $97.45 \pm 1.31$ \\
\hline $\mathrm{E}-1440$ & $57.71 \pm 3.01$ & $94.93 \pm 1.84$ \\
\hline
\end{tabular}

TABLE 3: Average Prostatic Acid Phophatase (ACP) Activity in the Serum.

\begin{tabular}{|c|c|c|}
\hline $\begin{array}{c}\text { Groups based on exposure time in } \\
\text { minutes }\end{array}$ & $\begin{array}{c}\text { Enzyme activity in the Serum } \\
\text { (iu/L) }\end{array}$ & Enzyme activity in the liver (iu/L) \\
\hline $\mathbf{A}-$ Control & $\mathbf{6 . 2 0} \pm \mathbf{0 . 3 4}$ & $\mathbf{0 . 7 0 \pm \mathbf { 0 . 1 1 }}$ \\
\hline $\mathrm{B}-10$ & $14.10 \pm 0.67$ & $0.15 \pm 0.03$ \\
\hline $\mathrm{C}-30$ & $9.62 \pm 0.52$ & $1.25 \pm 0.10$ \\
\hline
\end{tabular}




\begin{tabular}{|c|c|c|}
\hline $\mathrm{D}-60$ & $5.75 \pm 0.23$ & $0.10 \pm 0.01$ \\
\hline $\mathrm{E}-1440$ & $6.94 \pm 0.45$ & $0.55 \pm 0.04$ \\
\hline
\end{tabular}

\section{Discussion:}

The physical activities of the rats were observed. The control group was more agile than the exposed groups. The exposed groups were docile almost throughout the period of exposure.

The activity of alkaline phosphatase (ALP) in serum and liver of experimental animals in table 1 increased significantly $(\mathrm{p}<0.05)$ relative to the control, although the activity in group E exposed for 1440 minutes showed no significant difference ( $p>0.05$ ). This is in line with the work of Tomei et al., (1998) using some insecticides (carbamates, phosphoric esters and pyrethroids) they observed that significantly, more of the exposed workers had alkaline phosphatase activity outside the reference range (normal upper threshold -280 iu/L compared to $1.6 \%$ of controls ( $<0.05$ ). Srivastava et al., (1991) reported a significant increase in alkaline phosphatase activity which they suggested confirmed hepatic damage after exposure to the same class of pesticides. This increase in the experimental groups was dose dependent relative to the control. Green et al., (2005) advanced that it could result from induction/de novo synthesis of the enzyme due to treatment/introduction of an inducing agent.

The activity of total acid phosphatase (ACP) activity in the liver and the serum of experimental groups in table 2 showed no significant difference ( $>0.05)$ relative to the control. Table 3 indicated that there was slight fluctuations but with no significant difference ( $>0.05)$ in the activities of the prostatic acid phosphate when compared with the control. This is likely due to the fact that the organelle where this enzyme is localized (lysosome) was not affected by the toxic components of the insecticide. According to Akanji et al., (1996), ACP is located in the lysosome and any ingested compound that can affect the organelle affects its activity. This is possible as the compounds may have been metabolized in the liver before it could affect the other organelles.

These distortions and fluctuations in activities of the enzymes in some tissues of albino rats and many other symptoms experienced after acute exposure to Baygon insecticide gave a clear indication of hepatotoxic effect of the insecticides. These other symptoms may be due to changes in other hematological parameters such as proteins, carbohydrate and lipid concentrations, which may have significant changes as reported by Sakr et al., (2002) who observed a reduction in liver protein content and little decrease in RNA content of the liver following pyrethriod inhalation by albino rats.

\section{Conclusion:}

This result revealed that there was possible damage to liver cells which was indicated by the changes in the tramsaminase activities. Caution should be taken to avoid exposure to this insecticide or their components as even a short-time exposure can be toxic. It is therefore recommended that users should give room for proper ventilation of the room before entry to avoid toxic exposure to the insecticide.

\section{References}

[1] Akanji, M. A., Olagoke, O. A., Ipinmoye, T. I. and Oloyede, O. B. (1996). Effect of Chronic Consumption of Metasulphite on the Activities of Some Enzymes in Selected Tissues of Rays. Nigerian Journal of Biochemistry and Molecular Biology, 11 : 11 -15.

[2] Barbara, H. and Daniel, M. (2005). Basic Medical Laboratory Techniques, $5^{\text {th }}$ edition. Butherworth Publishers, London.

[3] Bhaynagar, V. K., Saigal, S., Khemani, L. D. and Malviya, A. N. (1982). Survey among Workers in Pesticide Factories. Toxicology. 10: $129-132$.

[4] Bohmont, B. L. (1990). The Students' Pesticide Users Guide. $8^{\text {th }}$ edition. Prentice-Hall inc, London, $170-221$

[5] Burtis, C. A. and Ashwood, E. R. (2003). TIETZ Fundamentals of Clinical Chemistry, $5^{\text {th }}$ edition. Elsevier, New Delhi, India.

[6] Carson, R. (1962). Silent Spring. Pesticides, 9: 10-15

[7] George, W. W. and David, M. W. (2004). An Introduction to Insecticides, $4^{\text {th }}$ edition, Meister Prof Information Resources.

[8] Green, T., Toghill, A., Lee, R., Peffer, R., Noakes, J. and Robinson, M. (2005). Thiamethoxan Induced Mice Liver Tumors and their Relevance to Human, Part 2: Species Differences in Response, Toxicology Science, 86(1): 48 - 55.

[9] Hassal, K. A. (1990) The Biochemistry and Use of Pesticides, $2^{\text {nd }}$ edition, Macmillan Press Limited,

[10] Igwenyi, I. O., Nwachukwu, N., Ibiam, U. and Offor, C. E. (2008). Effect of Insecticide (Baygon) on Transaminases Aactivities in Some Selected Tissues in Albino Rats. Journal Of Applied And Natural Sciences, 3(1) 46 - 48.

[11] Kumar, R., Bindu, A., Madhavi, N. B. and Sharma, C. B. (1993). Biodegradation of a Carbamate Pesticide, Propoxur, in Rat Tissues. Biochemical Chromatography, 7: 20-24.

[12] Nduka, N. (2000). Clinical Biochemistry for Students' Pathology, $3^{\text {rd }}$ edition, Macmillan Press Limited, Nigeria.

[13] Raju, S. M. and Bindu, M. (2005). Illustrated Medical Biochemistry. Jaypee Brothers Medical Publishers LTD. New Delhi. 179 $181,323-332$

[14] Sakr, S. A., El-Mesady, F. A. and Desouki, C. (2002). Histochemical Changes in Albino Rats Following Pyrethriod Inhalation. International Journal of Science, 2 (1): 24-28.

[15] Srivastava, A. K., Gupta, B. N., Mathur, A. K., Mathur, N., Mahendra, P. N. and Bharti, R. S. (1991). The Clinical and Biochemical Study of Pesticide sprayers. Human Experimental Toxicology, 10: 279-283.

[16] Tomei, F., Biagi, M., Baccolo, T. P., Tornao, E., Guntoli, P. and Rosatti, M. V. (1998). Liver damage among environmental disinfection workers, Journal of Occupational Health, 40: 193-197.

[17] Wilkinson, J. H., Baron, D. N., Moss, D. W. and Walker, P. G. (1972). Reference method for Aspartate and Alanine transaminases assay. Journal of Clinical Pathology on Standardization of Clinical Enzyme Assays. 